\title{
Challenges of Paperless Trade: Redesign of the Foreign Trade Processes and Bundling Functions of Traditional Documents
}

\author{
Mustafa Emre Civelek ${ }^{1}$, Murat Çemberci ${ }^{1}$, Nagehan Uca ${ }^{1}$, Ümit Çelebi $^{2}$, Abdurrahman Özalp ${ }^{3}$ \\ ${ }^{1}$ Faculty of Business Administration, Istanbul Commerce University, Istanbul, Turkey \\ ${ }^{2}$ Institute of Social Sciences, Istanbul University, Istanbul, Turkey \\ ${ }^{3}$ Head Office, Turkish Economy Bank, Istanbul, Turkey \\ Correspondence: Mustafa Emre Civelek, Faculty of Business Administration, Istanbul Commerce University, \\ Istanbul, Turkey. E-mail: ecivelek@ticaret.edu.tr
}

Received: December 15, 2016

Accepted: December 29, 2016

Online Published: January 6, 2017

doi:10.5539/ibr.v10n2p74

URL: http://dx.doi.org/10.5539/ibr.v10n2p74

\begin{abstract}
Technological innovations in recent years have resulted in paper based documentation will be completely abandoned in all business processes, however the paper-based processes still prevail in foreign trade transactions due to complicated business processes. Institution and companies in different countries involved in foreign trade transactions. Therefore integrative solutions are needed. This paper seeks to put forward a methodology to pave the way to the future international trade. Therefore we developed a taxonomical approach to this clutter in order to partially surmount the integration problem because a road map should be determined before the holistic solution. Taxonomical approach has been suggested for grouping the foreign trade documents in terms of their functions. All the parties participating in a foreign trade transaction should be able to connect to each other in a single online platform. There is a need for a single online platform of which all parties are members to complete a foreign trade transaction using a single integrated electronic document. Finally, opinions of the professional have been received for seeing the real procedures. Literature and practices have been synthesized and partial solution grouping the foreign trade documents in terms of their functions has been suggested. To constitute a base for the initial step of the road to integrated foreign trade document a taxonomical table has been prepared. Aim of this table to guide the firms that search for solutions to develop electronic equivalent of paper based documents.
\end{abstract}

Keywords: paperless trade, electronic documents, paperless customs

\section{Introduction}

Electronic documents are the electronic records produced by a computer program which bear electronic signature confirmed by a certificate authority. They are consists of the statements, writings, figures and pictures which are integrated as electronic record. And they should bear electronic signature in order to bind the party which issues this record. Electronic signature is a digital code attached to an electronic record to ensure the authenticity and authorization of the issuer. Electronic signatures are equivalent to handwritten signatures in terms of law. Electronic signing process is more secure than paper based signing process since trusted third party is used. Paper based signing prone to counterfeiting, therefore, retrospective issuance, alterations in formerly issued document and forged signatures are possible. This trusted third party is called as certificate authority or certification authority (CA). CA is an entity issuing digital certificates allows the parties participating in a transaction to rely upon each other. Legal validity of electronic signature depends upon e-signature laws. The majority of the countries have e-signature laws. But in the international level there are legal problems. In order to gain legal validity for electronic signature in international level multilateral agreements are needed. Multilateral agreements signed by the trading parties dispel the mistrust and clarify the legal status.

Today there is intense competitive business environment. In this environment foreign trade companies should focus on the costs. The majority of these costs are aroused from paper works. There are several drawbacks of paper work in addition to cost. Electronic documents improve process time and allow the users real time tracking. Thus reporting systems improve and decision making processes can be supported efficiently. But foreign Trade 
processes mostly depends on paper documents. Recently, the dependence on paper based documentation has been resolved only in few segment of foreign trade. For instance, in Turkey, customs declarations are completely issued in electronic environment. Systems such as e-AWB are continuously improving and adopted by some logistics companies. The European Commission has determined strategic goals of e-Custom development in Europe. Strategies focused on three concepts: pan-European interoperability, enabling single window and authorized economic operators (Razmerita \& Bjorn-Andersen, 2007).

Despite this progress, paper documents dominate the foreign trade transactions. Many companies are still using paper documents in their foreign trade processes in inefficient manner. Some of these companies are aware of the benefits of electronic documents. Since such change is expensive and need multilateral solutions, they freeze the problem as yet. Institution and companies in different countries should involve in a certain foreign trade transaction. Therefore complicated and multilateral business processes prevent companies from making such changes. International collaboration is required to be able to set up such an internet-based, third-party platform offering integrated documentation for foreign trade. And to establish such infrastructure, state support and involvement of international regulatory institutions are also needed.

\section{Methodology}

This paper seeks to put forward a methodology to pave the way to the future international trade. Therefore we developed a taxonomical approach to this clutter in order to partially surmount the integration problem because a road map should be determined before the holistic solution. Taxonomical approach has been suggested for grouping the foreign trade documents in terms of their functions. Due to the fact that recommending completely new system, this paper suggests fragmental approach to the problem as practicable step before final solution. Notwithstanding complicated business processes that need issuance of different type of documents far too numerous, dissect the integration problem may bring in incremental improvement in existing complexity. Early stage of this fragmental approach to make a taxonomic classification in terms of functions is to define issuers and users of the documents. Subsequently, functions of the documents must be defined. Finally, documents groups must be determined.

\section{Literature Review}

The greatest practical barrier to the promotion of electronic trade is the standardization of electronic documents (Financeasia, 2010). The concerted approach in the Asia region enhances harmonization of systems and procedures, which is necessary for continuous paperless trade processes (Laryea, 2005). Some of the problems in putting electronic document systems into practical use are not technical, but relate to psychological and management issues (Björk, 2006). Paper documents are still used in most offices, and employees still encounter some problems in using such documents. Some of these problems have been defined in earlier studies. These problems have persisted despite the development of hardware and software technology that have made electronic alternatives to paper documents available. Indeed the fragmentation between paper and electronic documents cause problems, but the fragmentation of electronic documents also cause problems. This confirms the need for more integrated paper and electronic document management systems (Jervis \& Masoodian, 2014).

In order to develop the international trade process, an e-Trade project was implemented by Korean government in 2003. In addition, to provide a single window for e-Trade, the uTradeHub was implemented in 2008. However, the evaluation of e-Trade performance was still controversial. The evaluation of e-Trade performance has both positive and negative results. Positive results were reported at the initial stage of e-Trade maturity, at the macro level, such as national, and at industrial levels. According to this view, e-Trade generally decreases transaction costs and increases productivity. However, recent literature has claimed some opposite results. Negative results were reported at the later stage of maturity as well as at the firm level. This means that the use of e-Trade is not continuously active when the benefits received do not match up with those expected. As a result, both the use and net benefits of e-Trade show steady levels, but not steady enough to increase a firm's capability. In addition, empirical research has shown similar results, such as in the case of Korea, where the number of SMEs using e-Trade is low and not increasing (Kim \& Lee, 2016).

Banks and insurance companies are faced with intense competitive pressure caused from demand-oriented market. This trend goes in line with the increasing usage of internet-based financial services. As a result, customers expect lower prices and fast and transparent service processing in all kind of financial products. However, a major drawback is the dependence of most banks on paper documents due to legal restrictions. Thus, a lot of paper is used in financial service companies, and is passed on between employees. To enable increases in efficiency, a major opportunity is seen in the digitalization of these documents (Leyer \& Hollmann, 2014). In China, internet-based, third-party internet service provider has been offering electronic bills of lading to 
facilitate international supply chain processes. But for changing user attitudes towards electronic bills of lading, there is a need to build trust (Mei \& Dinwoodie, 2005). Results regarding attitude of the users was dubious because electronic documents are conspicuously advantageous. Benefits such as cost reduction, shorter transaction time, elimination of archive problem and prevention of fraud are undeniable. Employees' negative attitude against electronic document system most probably arises from resistance to change and lack of system interoperability. Full web based usability and making possible all the related parties to use the integrated system simultaneously may eliminate user hesitations (Civelek \& Sözer, İnternet Ticareti: Yeni EkoSosyal Sistem ve Ticaret Noktaları, 2003). Main participants of a foreign trade transaction are exporter, importer, carrier, insurance company, customs administration and bank. For full integration of all these parties need to come together.

To be able to conduct foreign trade by means of electronic documents, the existing foreign trade payment methods should also be simplified and adapted to the electronic environment. It is unnecessary to use the same detailed procedures. Electronic environment allows removing the difficulties of paper based business processes. In electronic environment it will be appropriate to use a single standard to replace classical payment methods if possible (Civelek, Uca, \& Çemberci, 2015) such as BPO.

Standardization of electronic documents has an important role for increasing the connectivity of all parties involved in the global supply chain processes and automating international trade in the global supply chain. Therefore web-based supply chain system has become an increasingly important goal and got much attention from governments and international organizations as well. There have been many theoretical, technological and practical literatures on e-SCM, but relatively few on the global e-SCM, especially focusing on the automation of information flow in the global business. In Table 1, four procedures involved in international trade transaction are shown (Moon, Shim, \& Kim, 2011).

The most important success factors in the transactions and information exchange among global business partners is the standardization of electronic documents. These indisputably lead to the conclusion that integrated electronic document system is certainly needed. The single window can be defined as a facility that allows parties involved in trade and transport to share standardized trade-related information and/or issue documents in a single system to fulfill all the requirements of the foreign trade transactions. According to staged approach to single window leads full integration of all the parties involved in foreign trade transactions.

As shown in Table 2, staged approach envisages five stages to developing ideal single window. Indeed, many developed countries do not have a national single window or have only recently started to work on single window implementation. Most countries of the European Union, for example, have no national single window.

Table 1. Four Procedures Involved In International Trade Transaction

\begin{tabular}{ll}
\hline Procedures & Activities \\
\hline & Establish a contract \\
Order goods \\
Commercial Procedures & Advise on delivery \\
& Request payment \\
& Packing \\
& Inspection \\
& Certification \\
& Accreditation \\
& Warehousing \\
\hline \multirow{3}{*}{ Transport Procedures } & Establish a transport contract \\
& Receipt, shipment and deliver of goods \\
& Provide waybills, goods receipts, status reports, etc. \\
\hline \multirow{2}{*}{ Regulatory Procedures } & Obtain import/export licenses \\
& Provide customs declarations \\
& Provide cargo declaration \\
& Apply trade security procedures \\
& Clear goods for export/import \\
\hline & Provide credit rating \\
Financial Procedures & Provide insurance \\
& Provide credit \\
& Execute payment \\
\end{tabular}

Source: (Moon, Shim, \& Kim, 2011)

On the other hand, many countries in Africa, Asia and Latin America have started or completed national single windows. As first stage, some limited forms of the single window have been established. Prevalent 
implementation of these limited forms is customs single windows. This essentially provides a single interface between the trading community and the Customs Authority. In some cases of single window have been implemented in subnational level, whereby the local trade community and regulatory agencies can be grouped together at city or provincial level to establish a trade community single window platform (Tsen, 2011). These attempts do not lead the final solution because an international electronic document platform is needed to integrate all the parties involved in a foreign trade transaction. Partial and local electronic documents platforms do never get the desired results.

As shown in Table 2 staged approach contemplates step by step improvement starting customs transactions to transport documents and e-payment. But there is a need for a revolutionary breakthrough to integrate international transactions in supply chain processes.

Studying on preparation of the electronic version of each paper document issued in supply chain should be abandoned because issuance separate document in electronic environment is not necessary. A unique platform having the functions of all documents can replace paper documents. Definition of the documents can evolve. Consecutive functions can be assigned on a single document title. Mind set should be changed and new document titles should be created. Electronic trade facilitation entails the establishment of online trade platforms through which all the parties involved in trade (exporters, importers, customs brokers, carriers, freight forwarders, financial institutions and relevant government agencies) interact with each other electronically (McMaster, 2006). Trade facilitation is a concept that considers the simplification, harmonization, standardization and modernization of trade procedures.

Table 2. Staged approach to developing a single window

\begin{tabular}{ll}
\hline Stages & \multicolumn{1}{c}{ Activities } \\
\hline $1^{\text {st }}$ Stage & Paperless customs, e-payment for customs duty, container loading list, simple e-documents exchange with \\
port or terminal authority & Connecting other government IT systems, e-permit exchange with paperless customs system \\
$2^{\text {nd }}$ Stage & e-Documents exchange stakeholders within the port community \\
$3^{\text {rd }}$ Stage & An integrated national logistics platform with also trader and logistics service providers \\
$4^{\text {th }}$ Stage & A regional information exchange system \\
$5^{\text {th }}$ Stage &
\end{tabular}

Source: (Tsen, 2011)

Its principle aim is to reduce transaction costs in international trade, especially those between business and government actors at the national border.

Table 3. International Involving Parties

\begin{tabular}{ll}
\hline Types of Involvement & Parties \\
\hline & Exporter \\
& Importer \\
Purchasing \& Supplying & Manufacturer \\
& Shipper \\
& Consignee \\
& Commission Agent \\
& Export Agent \\
\hline \multirow{2}{*}{ Regulation } & Chamber of Commerce \\
& Consular \\
\hline \multirow{2}{*}{ Financial Activities } & Customs \\
\hline \multirow{2}{*}{ Carriage } & Inspection company \\
\hline
\end{tabular}

It is defined by the WTO as: The simplification and harmonization of international trade procedures where trade procedures are the activities, practices and formalities involved in collecting, presenting, communicating and processing data required for the movement of goods in international trade. International trade operations are substantially complex, involving many parties and operational steps (Grainger, 2007). In Table 3 some of the involving parties are shown. In order to reduce the complexity of international trade transactions and the costs related to them, the United Nations Centre for Trade Facilitation and Electronic Business (UN/CEFACT) recommends the implementation of the following measures (De, 2011):

- Simplify and harmonize trade procedures and, where possible, eliminate unnecessary ones.

- Simplify and coordinate administrative procedures at border crossings. 
- Simplify payment systems.

- Simplify, standardize and harmonize the documents required for trade transactions.

- Facilitate the flow of information that controls the movement of goods throughout the transaction (e.g. by applying information and communication technology).

- Enhance trust assessment through better exchange of information.

Steps toward an electronic single window and paperless trade environment are recommended as follows (De, 2011):

- Business process analysis

- Process simplification and harmonization

- Documents simplification and alignment

- National data harmonization

- Cross-border data harmonization and exchange

- e-Single Window and Paperless Trade platform

\section{Towards the Final Solution}

\subsection{Paperless Customs}

Digitalization of customs processes plays an important role in the simplifying and facilitating trade. Many customs authorities around the world have recently put in place major modernization projects not only through their own national vision and initiatives but also with and under the guidance and assistance of international organizations (World Bank, IMF, WTO, WCO etc.) to facilitate trade, strengthen customs control and enable risk management more effectively (Wulf \& McLinden, 2005). As such, amongst those emerging economies that have being going through customs modernization, Turkey stands in the leading position as the country has transformed from a paper-based customs processes to an electronic one in such a short period of time together with the implementation of customs union agreement with EU signed and entered into force since 1996. Not only with brand new customs law (which is quasi-identical to EU Customs Code) introducing more liberal customs procedures and regimes replaced the archaic-one reminiscent of the protectionist era of $70 \mathrm{~s}$ and $80 \mathrm{~s}$, but also a major customs modernization project was kicked off in parallel with the World Bank financial assistance program which provided an impetus to complete overhaul of manual processes where pen and paper were to be taken over then by computers and EDI (Electronic Data Interchange). And yet the process was and is by no means an end but only a start of a new way of life for customs and trade community. In fact, as of now, data is still being supplemented with the hardcopy print-outs of declarations and supporting documents, originally signed and submitted to Turkish Customs continuing to cause unnecessary costs and workloads. Elimination of hard-copy paperwork hand-over process and accepting the electronic data as a 'sole medium' to complete customs formalities will therefore further enhance the digitalization of Customs Processes as this would be the ultimate aim. Nevertheless number of initiative came one after another towards a complete paperless customs environment. Amongst which is currently taking place is 'single window' initiative where necessary local authority permission process under the remit of each and every ministerial functions to be enacted via an electronic system. Once an operator has uploaded the data and necessary paperwork in the system then approval process would take place electronically in the background between customs and concerning public authorities hence eliminating physical handling and follow up. This not only reduces the cost of transaction but also increases the speed, effectiveness and control. To further improve the process, it is advised that an operator should be given the right of a 'single registration' at the front-end without going through multiple registration process at each and every ministerial level so as to eliminate an upload of identical registry documents every now and then (Çelebi, 2016).

\subsection{Bank Payment Obligation}

BPO (Bank Payment Obligation) is another new payment method which allows for the electronic presentation of data that has been extracted from the underlying paper or electronic documents. BPO is a new payment method which combines security of the L/C (Letter of Credit) with easiness of the Open Account. On one hand, it can complement banks' ability to assist in open account trade with a range of risk mitigation, payment assurance and financing options. On the other hand, leading enterprises and corporates have used BPO to reduce the cost and eliminate the commonly recognized operational inefficiencies associated with documentary letters of credit. BPO has been developed by SWIFT (Society for Worldwide Interbank Financial Telecommunication) and ruled by 
ICC (International Chamber of Commerce), Paris. It strongly supports using of the electronic documents in trade whether in domestic or international. BPO works on an electronic platform which called TMA (Transaction Matching Application). Firstly, Buyer or Seller send their Purchase Order information their banks to enter the electronic platform i.e.TMA, to be ready for matching the data sets after shipment with a baseline that had been entered before shipment. For this purpose a baseline creates with that information in the TMA waits for making matching, henceforth buyer bank takes an irrevocable obligation and called "Obligor bank". After a shipment seller send his data sets that has been extracted from the underlying paper or electronic documents. TMA starts matching transaction in order to produce a report as data match or mismatch. If TMA sends a "Data Match Report" to involved parties then the Obligor pays at sight or incurs a deferred payment obligation according to the condition of the BPO in the baseline (Özalp, 2014).

Table 4. Taxonomic Classification of Foreign Trade Document

\begin{tabular}{|c|c|c|c|c|c|}
\hline CLASS & TITLE & FUNCTION & ISSUER & $\begin{array}{l}\text { OTHER PARTIES } \\
\text { THAT CAN ADD } \\
\text { INFORMATION }\end{array}$ & BEING VIEWED BY \\
\hline \multirow{5}{*}{ TRANSPORT } & Bill of Lading & $\begin{array}{l}\text { Receipt of the Goods } \\
\text { and/or Shipment of the } \\
\text { Goods and possession } \\
\text { of goods }\end{array}$ & $\begin{array}{l}\text { "Carrier" or "Agent of the } \\
\text { Carrier" or "Master" }\end{array}$ & Banks & $\begin{array}{l}\text { Shipper, Consignee, } \\
\text { Customs Agent }\end{array}$ \\
\hline & CMR & Shipment of the Goods & $\begin{array}{l}\text { "Carrier" or "Agent of the } \\
\text { Carrier" }\end{array}$ & $\begin{array}{l}\text { None } \\
\text { (Non-negotiable) }\end{array}$ & $\begin{array}{l}\text { Shipper, Consignee, } \\
\text { Customs Agent }\end{array}$ \\
\hline & Air Waybill & Shipment of the Goods & $\begin{array}{l}\text { "Carrier" or "Agent of the } \\
\text { Carrier" }\end{array}$ & $\begin{array}{l}\text { None } \\
\text { (Non-negotiable) }\end{array}$ & $\begin{array}{l}\text { Shipper, Consignee, } \\
\text { Customs Agent }\end{array}$ \\
\hline & Rail Waybill & Receipt of the Goods & $\begin{array}{c}\text { "Carrier" or "Agent of the } \\
\text { Carrier" }\end{array}$ & $\begin{array}{l}\text { None } \\
\text { (Non-negotiable) }\end{array}$ & $\begin{array}{l}\text { Shipper, Consignee, } \\
\text { Customs Agent }\end{array}$ \\
\hline & FCR & Receipt of the Goods & Forwarder & $\begin{array}{l}\text { None } \\
\text { (Non-negotiable) }\end{array}$ & $\begin{array}{l}\text { Shipper, Consignee, } \\
\text { Customs Agent }\end{array}$ \\
\hline \multirow{2}{*}{ INSURANCE } & $\begin{array}{l}\text { Insurance } \\
\text { Policy }\end{array}$ & $\begin{array}{l}\text { Insure the goods } \\
\text { against the risks of } \\
\text { logistics processes }\end{array}$ & Insurance company or agent & Banks & $\begin{array}{l}\text { Shipper, Consignee, Banks, } \\
\text { Customs Agent }\end{array}$ \\
\hline & $\begin{array}{l}\text { Insurance } \\
\text { Certificate }\end{array}$ & $\begin{array}{l}\text { Insure the goods } \\
\text { against the risks of } \\
\text { logistics processes }\end{array}$ & Insurance company or agent & Banks & $\begin{array}{l}\text { Shipper, Consignee, Banks, } \\
\text { Customs Agent }\end{array}$ \\
\hline \multirow{5}{*}{$\begin{array}{l}\text { MOVEMENT \& } \\
\text { ORIGIN }\end{array}$} & $\begin{array}{l}\text { Certificate of } \\
\text { Origin }\end{array}$ & $\begin{array}{l}\text { Signify the origin of } \\
\text { the goods }\end{array}$ & $\begin{array}{l}\text { Issued by exporter and legalized } \\
\text { by local chamber of commerce } \\
\text { and customs authority }\end{array}$ & $\begin{array}{l}\text { chamber } r \\
\text { commerce, customs } \\
\text { authority }\end{array}$ & $\begin{array}{l}\text { Departure customs, destination } \\
\text { customs, consignee, banks, } \\
\text { forwarders, customs agent }\end{array}$ \\
\hline & A.TR & $\begin{array}{l}\text { Signify the origin of } \\
\text { the goods }\end{array}$ & $\begin{array}{l}\text { Issued by exporter and legalized } \\
\text { by local chamber of commerce } \\
\text { and customs authority }\end{array}$ & $\begin{array}{lr}\text { chamber } & \text { of } \\
\text { commerce, customs } \\
\text { authority }\end{array}$ & $\begin{array}{l}\text { Departure customs, destination } \\
\text { customs, consignee, banks, } \\
\text { forwarders, customs agent }\end{array}$ \\
\hline & Eur.1 & $\begin{array}{l}\text { Signify the origin of } \\
\text { the goods }\end{array}$ & $\begin{array}{l}\text { Issued by exporter and legalized } \\
\text { by local chamber of commerce } \\
\text { and customs authority }\end{array}$ & $\begin{array}{l}\text { chamber } r \\
\text { commerce, customs } \\
\text { authority }\end{array}$ & $\begin{array}{l}\text { Departure customs, destination } \\
\text { customs, consignee, banks, } \\
\text { forwarders, customs agent }\end{array}$ \\
\hline & Form A & $\begin{array}{l}\text { Signify the origin of } \\
\text { the goods }\end{array}$ & $\begin{array}{l}\text { Issued by exporter and legalized } \\
\text { by local chamber of commerce } \\
\text { and customs authority }\end{array}$ & $\begin{array}{lr}\text { chamber } & \text { of } \\
\text { commerce, } & \text { customs } \\
\text { authority } & \\
\end{array}$ & $\begin{array}{l}\text { Departure customs, destination } \\
\text { customs, consignee, banks, } \\
\text { forwarders, customs agent }\end{array}$ \\
\hline & Form B & $\begin{array}{l}\text { Signify the origin of } \\
\text { the goods }\end{array}$ & $\begin{array}{l}\text { Issued by exporter and legalized } \\
\text { by local chamber of commerce } \\
\text { and customs authority }\end{array}$ & $\begin{array}{lr}\text { chamber } & \text { of } \\
\text { commerce, customs } \\
\text { authority }\end{array}$ & $\begin{array}{l}\text { Departure customs, destination } \\
\text { customs, consignee, banks, } \\
\text { forwarders, customs agent }\end{array}$ \\
\hline \multirow{3}{*}{ CONFORMANCE } & $\begin{array}{l}\text { Analysis } \\
\text { Certificate }\end{array}$ & $\begin{array}{l}\text { Signify the chemical } \\
\text { analysis results }\end{array}$ & Laboratories & None & $\begin{array}{l}\text { Departure customs, destination } \\
\text { customs, consignee, banks, } \\
\text { forwarders, customs agent }\end{array}$ \\
\hline & $\begin{array}{l}\text { Health } \\
\text { Certificate }\end{array}$ & $\begin{array}{l}\text { Signify health of the } \\
\text { live stocks and their } \\
\text { products }\end{array}$ & Minister of Agriculture & None & $\begin{array}{l}\text { Departure customs, destination } \\
\text { customs, consignee, banks, } \\
\text { forwarders, customs agent }\end{array}$ \\
\hline & $\begin{array}{l}\text { Phytosanitary } \\
\text { Certificate }\end{array}$ & $\begin{array}{l}\text { Signify health of the } \\
\text { plants and herbal } \\
\text { products }\end{array}$ & Minister of Agriculture & None & $\begin{array}{l}\text { Departure customs, destination } \\
\text { customs, consignee, banks, } \\
\text { forwarders, customs agent }\end{array}$ \\
\hline \multirow{3}{*}{ INVOICE } & Proforma & $\begin{array}{l}\text { Proposal and/or } \\
\text { acceptance of the order }\end{array}$ & Exporter & Importer & Importer \\
\hline & $\begin{array}{l}\text { Commercial } \\
\text { Invoice }\end{array}$ & Certify the final sale & Exporter & None & $\begin{array}{l}\text { Departure customs, destination } \\
\text { customs, importer, banks, } \\
\text { forwarders, customs agent }\end{array}$ \\
\hline & $\begin{array}{l}\text { Freight } \\
\text { Invoice }\end{array}$ & $\begin{array}{l}\text { Certify the freight } \\
\text { amount }\end{array}$ & Transporter & None & $\begin{array}{l}\text { Departure customs, destination } \\
\text { customs, importer, banks, } \\
\text { forwarders, customs agent }\end{array}$ \\
\hline
\end{tabular}




\begin{tabular}{|c|c|c|c|c|c|}
\hline INSPECTION & $\begin{array}{l}\text { Inspection } \\
\text { (Surveillance) } \\
\text { Certificate }\end{array}$ & $\begin{array}{l}\text { Certifies the goods } \\
\text { meets the required } \\
\text { specifications }\end{array}$ & Inspection Companies & None & Importer, Banks \\
\hline
\end{tabular}

\section{Discussion \& Conclusion}

Inclusion of e-Signature into internet of things and M2M technologies can make it possible to reach completely paperless trade processes. In the future no-Document in trade process will be discussed instead of paperless trade (Cisco, 2015). Technological innovations in recent years have resulted in paper based documentation will be completely abandoned in all business processes, however the paper-based processes still prevail in foreign trade transactions due to complicated business processes. Institution and companies in different countries involved in foreign trade transactions. Therefore integrative solutions are needed.

In this paper the integration problem in foreign trade documents is defined. Then detailed literature review has been performed. Subsequently, opinions of the professional have been received for seeing the real procedures. After discussing, literature and practices have been synthesized and partial solution grouping the foreign trade documents in terms of their functions has been suggested. To constitute a base for the initial step of the road to integrated foreign trade document a taxonomical table has been prepared. Aim of this table to guide the firms that search for solutions to develop electronic equivalent of paper based documents.

\section{References}

Björk, B. C. (2006). Electronic document management in temporary project organisations-Construction industry experiences. Online Information Review, 30(6), 644-655. https://doi.org/10.1108/14684520610716144

Cisco, A. C. (2015). Internet of Things in Logistics. Toisdorf: DHL Trend Researc and Cisco Consulting Services.

Civelek, M. E., \& Sözer, E. G. (2003). Internet Ticareti: Yeni EkoSosyal Sistem ve Ticaret Noktaları. İstanbul: Beta Basim.

Civelek, M. E., Uca, N., \& Çemberci, M. (2015). eUCP and Electronic Commerce Investments:e-Signature and Paperless Foreign Trade. Eurasian Acadeny of Sciences Eurasian Business \& Economics Journal, 3(1), 60-70.

Çelebi, Ü. (2016). The Impact of Logistics Performance upon Economic Growth: A Proposal of a Conceptual Model from the perspective of EU-Turkey Customs Union Dynamic Effects. Working PhD thesis. İstanbul: Istanbul University.

De, P. (2011). Trade Facilitation in India: An Analysis of Trade Processes and Procedures. Bangkok: ARTNeT Working Paper Series.

Financeasia. (2010). Attracting Corporate Customers through Paperless Trade. Trade Finance Year Book (s. 42-43). içinde Grainger, A. (2007). Trade Facilitation: A Review. Surrey: Trade Facilitation Consulting Ltd.

Jervis, M., \& Masoodian, M. (2014). How do people attempt to integrate the management of their paper and electronic documents? Aslib Journal of Information, 66(2), 134-155. https://doi.org/10.1108/AJIM-01-2013-0007

Kim, H. M., \& Lee, H. H. (2016). Asset specificity and capability of e-Trade performance: evidence from Korea. Journal of Korea Trade, 20(1), 2-20. https://doi.org/10.1108/JKT-03-2016-001

Laryea, E. (2005). Facilitating Paperless International Trade: A Survey of Law and Policy in Asia. International Review Of Law Computers, 19(2), 121-142. https://doi.org/10.1080/13600860500131200

Leyer, M., \& Hollmann, M. (2014). Introduction of electronic documents: how business process simulation can help. Business Process Management, 20(6), 950-970. https://doi.org/10.1108/BPMJ-05-2013-0062

Mcmaster, J. (2006). The Evolution of Electronic Trade Facilitation: Towards a Global Single Window Trade Portal. The Electronic Journal of Information, 1-19.

Mei, Z., \& Dinwoodie, J. (2005). Electronic shipping documentation in China's international supply chains. Supply Chain Management: An International Journal, 10(3), 198-205. https://doi.org/10.1108/13598540510606250 
Moon, H. C., Shim, S. R., \& Kim, D. Y. (2011). Issues in the International Standards of Electronic Documents for Global e-Trade. the International Conference on Social Science, Economics and Art (s. 164-168). Bangi-Putrajaya: ISC.

Özalp, A. (2014). BPO'nun Kullanılması. İstanbul: Türkmen Kitapevi.

Razmerita, L., \& Bjorn-Andersen, N. (2007). Towards Ubiquitous e-Custom Services. IEEE/WIC/ACM International Conference on Web Intelligence (s. 833-837). Copenhagen: IEEE. https://doi.org/10.1109/WI.2007.148

Tsen, J. K. (2011). Ten Years Of Single Window Implementation: Lessons Learned For The Future. Global Trade Facilitation Conference, (s. 1-26).

Wulf, L. D., \& McLinden, G. (2005). The role of Information Technology in Customs Modernization. L. D. Wulf, \& J. Sokol içinde. Customs Modernization Handbook (s. 285-310). The Worl Bank.

\section{Copyrights}

Copyright for this article is retained by the author(s), with first publication rights granted to the journal.

This is an open-access article distributed under the terms and conditions of the Creative Commons Attribution license (http://creativecommons.org/licenses/by/4.0/). 